\title{
Learning to be Human: From Philosophical Problem to Humanity Development Metaphor
}

\author{
Maryna Liashenko \\ Ph.D., National Pedagogical Dragomanov University (Kyiv, Ukraine) \\ E-mail: liashenko_m@npu.edu.ua \\ https://orcid.org/0000-0002-8439-2587 \\ Oksana Subina \\ Ph.D., National Pedagogical Dragomanov University (Kyiv, Ukraine) \\ E-mail: o.o.subina@npu.edu.ua \\ https://orcid.org/0000-0001-8167-539X
}

This study is an authorial attempt to develop the ideas of the $24^{\text {th }}$ World Congress of Philosophy (China, 2018). This intellectual event aimed to discuss a number of problems within the need to preserve Human (the slogan of the event was the idea of "Learning to be Human"). The authors analyze sociocultural challenges that require rethinking the ways to remain Human, and extend the problematic field to the pressing problem of space exploration that was overlooked by the World Congress participants. The article is an attempt to substantiate the answers to the following questions: Will, and can, Humanity retain its own traditional humanistic authenticity in the context of rapid technological development and space exploration? Is Humanity Capable of Humanistic Development as a whole, and what is the Role of Education and Intellectuals in the Age of Modern Value Turbulence? It has been argued that New Enlightenment can offer an adapted ethical platform for Humanity that can be appropriately transmitted by means of value-updated education tools.

Keywords: humanity, education, education values, civilization development, space exploration, New Enlightenment, World Congress of Philosophy

Received: June 17, 2019; accepted: July 12, 2019

Philosophy and Cosmology, Volume 24, 2020: 113-121.

https://doi.org/10.29202/phil-cosm/24/11

\section{Introduction}

The organizers of the $24^{\text {th }}$ World Congress of Philosophy, held in Beijing in the summer of 2018, emphasized that this landmark event should act as an intellectual platform to find ways to develop civilization, providing a productive response to the challenges of technology development, the contradictions of globalization: "Learning to be Human" is the

\footnotetext{
(C) Liashenko, Maryna, 2020

(C) Subina, Oksana, 2020
} 
theme of the $24^{\text {th }}$ World Congress of Philosophy. We believe that philosophers can identify different dimensions of thinking about humans in response to this theme. Nowadays, the advance of modern science and technology not merely improves human life but also causes unprecedented challenges and crises. Conflicts between civilizations and between nations, tensions between individual and community and between different individuals as well as disquiet in each of us are all in need of philosophical wisdom. It is simply impossible to find out any ready-made solutions. However rational reflection and dialogue may help to create a better world and to gain an individual life more adapted to our times" (Learning, 2018). Indeed, modernity, with its unprecedented spread of technology, threatens the possibility of Humanity development, the principles of which were outlined by the anthropological project of the Modern Age. Technological advancement should receive appropriate reflection from intellectual elites who would offer ways to ensure a harmonious combination of "human" and technological. This approach should save Humanity from the rapid and risky steps in the era of "digital barbarism", returning not only to pre-Modern by content cultural practices, but also to their unprecedented spread using the technological advances of modern digital civilization (Kleszczyński, 2019).

The previous 23 $3^{\text {rd }}$ World Congress of Philosophy, held in 2013 in Athens, was dedicated to the topic Philosophy as inquiry and way of life. The organizers of the Congress described the issue as follows: to inquire into the world's philosophical traditions and compare them in terms of their diverse contributions and possible mutual cross-fertilization; to reflect on the tasks and functions of philosophy in the contemporary world; to emphasize the importance of philosophical reflection for public discourse on global issues affecting humanity" (Philosophy, 2013). Thus, the world philosophical community, whose efforts are united by the activities of the International Federation of Philosophical Societies (FISP), is once again trying to offer a philosophical understanding of the ways of civilization development on a humanistic ethical platform, which would minimize the challenges of the realization of technogenic scenarios and conflicts of intercultural interaction. It is clear that large-scale transformations of civilizational nature are a challenge for education as a sociocultural institute, as well as for the established, traditional practices of transmitting cultural experiences, hence in the attempts to offer ways for Humanity to remain human, an important place is given to the philosophy of education.

The authors of the article also propose to expand the problem under consideration, arguing not only with a wide range of the authors who offer ideas on how to learn to be Human in the modern day. In our view, as participants of the $24^{\text {th }}$ World Congress of Philosophy, there remain complex questions regarding the active exploration of space by Humanity. This is not an indication of the inconsistency of this venerable event with the real needs of humanity; on the contrary, the Congress members focused on the most pressing issues of the civilization development agenda. In our article, we seek to expand the problematic field by enhancing the futurological value of the ideas suggested in the article, which will be of use to Humanity not only as a planetary phenomenon, but also as a phenomenon that unfolds itself on a scale of the Universe. Thus, the authors will try to offer the answers to the following questions: Will, and can, humanity retain its traditional humanistic authenticity in the context of rapid technological development and space exploration? Is Humanity capable of humanistic development in general, and what is the role of education and intellectuals in the Age of Modern Value Turbulence? 


\section{A Classic Humanist Project as a Reference Point of the Research}

Given the current global problems and prospects for the development of human society, the concept of humanity is of particular importance. Its meaning is revealed in such meaningful projections.

1. Humanity as the core value that determines the horizon of human activity.

In this sense, the concept is determined etymologically, so the basis of its semantics is focused on the normativity of interaction between people in the context of the problem of biological species survival. Thus, Johann Frick analyzes the problem of humanity as an axiological basis for the strategy of human survival. On the one hand, the content of humanity is to increase the number of happy lives of individuals, and on the other, to implement the principle of equality of all people. Therefore, the so-called intuition of neutrality is justly criticized as inappropriate given the ultimate value of humanity itself: "This conclusion would only follow if our reasons for wanting there to be humans in the future were at the same time reasons for wanting humanity to have existed in the pre-historic past. And this, again, would only be true on a conception of final value as something to be promoted. On the understanding of final value that animates the Argument from the Final Value of Humanity, our reasons for wanting humans to exist in the future are not temporally neutral. Rather, they stem from our concern for the survival of those things we value finally" (Frick, 2017: 362). Accordingly, the problem of Humanity survival requires active and decisive action, but it is not of value in itself. This problem has been exacerbated in the light of the active space exploration, since it poses a number of praxeological and ethical problems to Humanity.

The valuable phenomena of human existence are those that are traditionally associated with humanity: love, care, knowledge, and beauty. Therefore, it is natural that the concept of humanity is complex, and it is not limited to the absolutization of one of the components. Yes, for a long time, the essential predication of human was considered rationality. However, if we identify rationality with intellectual development, it is obvious that not only man has such abilities. The behavior of animals, especially social animals, also contains some rationality in the strategies for adapting to and interacting with the world. Thus, at the turn of the millennium, David Woolfson categorically proves the connection between the way of thinking as a certain axiological system and the way of acting as a strategy for achieving this goal. His views are both balanced and optimistic: "For the first time in human history a global consensus on universal societal values may be capable of being formed. This is due to new understandings and our ability to communicate globally. We would in essence be agreeing upon the collective wisdom of humankind at this point in our evolution" (Woolfson, 2000: 193). Therefore, the author foresees significant social transformations in the future: "The current crisis facing humanity presents us with both enormous challenges and tremendous opportunities. In overcoming our challenges, we will emerge with a new society. It will be global, diverse and sustainable. There will be a mega-shift in societal thinking from focusing on the past to shaping the future. From domination, control, confrontation and exploitation to nature's way of partnership, balance, harmony and sustainability. All of society's institutions, organizations, systems and structures will be transformed accordingly" (Woolfson, 2000: 200). Thus, this is the understanding of humanity as a specific feature of human being that forms the idea of the impact of this concept on the social system and the realization of the principle of social justice.

2. Humanity as a prerequisite for social justice.

The concept of humanity, in its original meaning, contains a principled position on equality for all people. Human is attributively social, so society is a field of formation and 
realization of humanity. Only if human is recognized as a value, a just social system is possible. However, such seemingly axiomatic theses can be employed as mechanisms of manipulation and exploitation. On the one hand, the authors are right when actualizing the problem of the impossibility of progress in the field of values, humanity in particular. But both moral, ethical and legal laws differ geopolitically, historically and retrospectively. Accordingly, the findings of Jack Donnelly, who provided a thorough analysis of the categories of humanity and equality, are justified. In his view, these concepts function as particularistic principles of the hierarchy, as a criterion for belonging to a particular community. In this interpretation, humanity and dignity are the mechanisms of social recognition and respect: "A normative human being is a creature with certain qualities (e.g., virtue, reason, or a soul) that demand recognition and respect. A taxonomic human being is a creature with certain biological features (e.g., Aristotle's featherless biped). Internationally recognized human rights take it for granted that these two classes are identical and that all taxonomic humans are normative humans (and vice versa). Historically, however, the class of taxonomic humans has usually been much larger than that of normative humans - or, in societies that did not speak of humanity, men of dignity" (Donnelly, 2015: 2).

The content components of humanity, as the core ideals and values, have been applied to various manipulative technologies, both historically and today. It is significant that these manipulations are realized in two ways: as the presence of the Other, the interaction that requires the determinant of humanity (another race, religion, political power, animal, nature, thing, etc.) and as social cohesion based on shared values and goals of life. In this way, the world is divided into "one's own" and "other's", and justifies the appointment of humanity as a unification and combination of all individuals and communities on the basis of common ideals and aspirations.

This integration takes place in the global communicative space of the modern world civilization. Accordingly, John Hartley regards humanity as a substance of human communication and interaction. Such a status of humanity is conditioned by the evolution of semiotic history, in which the concept's content from static and universal form moves to contextuality and realization. Therefore, the author comes to the conclusion that there is an evolutionary process of new human formation, whose mission is to promote humanity in society: "Messaging humanity" allows us to think about "the message" not as an external packet but as a constitutive property of humanity. This property is not new, although it has been precipitated into increased visibility recently because technological and scientific developments have allowed the messaging aspect to be observed more accurately. For instance, where once we could only talk metaphorically and abstractly about entities such as "the reading public," now we can observe and measure it directly at any given moment, for instance via clickstream and sales-tracking data" (Hartley, 2010: 305). Indeed, it is the communicative discourse that determines the content of the concept of humanity and its trajectory. For example, John Lattimore and Mickey Lauria convincingly argue that the financial indicators of wealth or poverty do not determine the axiology of humanity (Lattimore \& Lauria, 2018). Therefore, it is reasonable to believe that humanity is the embodiment of the European paradigm of thinking, behavior, assessments and priorities. That is why there are so many critics of the concept of universal values, the pathos of humanity and the criteria of justice. However, reasonably certain and fair implementation of the humanitarian principle is considered to be the Declaration of Human Rights and the mechanisms for its implementation. 
3. Humanity as a prerequisite for the emergence and worldwide recognition of human rights.

The concept of humanity is often criticized because of its declarative nature, the lack of clear and effective mechanisms and programs for implementation. Indeed, it is absurd to set any criteria for measuring humanity. However, fruitful and systematic work at the international level on human rights is an important and effective factor in promoting humanity. Daniel S. Malachuk is convinced that the debate on the fundamentality of human rights is not a matter of rationalization, but rather a post-secular axiom of humanity as an undeniable value. This position avoids religious radicalism in substantiating the value of human life and focuses on the belief of the religion of humanity: "The first point is that most human rights histories follow the secularization thesis: a thesis that flatters anti-foundationalist conclusions but is not in fact accurate. The secularization thesis and the human rights histories that echo it are histories of subtraction, according to which the death of God and metaphysics meant the birth of rights. So long as human rights historians continue to subscribe to the secularization thesis we will never be in a position to appreciate what nineteenth-century religions of humanity actually contributed - and could once again contribute - to human rights theory" (Malachuk, 2010: 137).

Of course, human rights are more of a goal than a fact. It is no coincidence that the observance of these rights geographically coincides with those regions where the perception of the principles of humanity has been traditionally and historically formed. Accordingly, Andreas Schüller points out that in the context of numerous local conflicts around the world, the principles of humanity are declarative: "Supporting the need for fundamental standards of humanity, there have been developments in human rights law, such as further interpretations of treaties, e.g. by General Comments of the Human Rights Committee on the Political Covenant, or case-law emerging from regional human rights courts, in particular the European Court of Human Rights and the Inter-American Court of Human Rights" (Schüller, 2010: 760). Thus, the author proposes to prepare a document that, on the basis of international humanitarian law, will ensure the protection of human rights at all levels and even in extreme conditions.

Therefore, in the light of modern events, humanity is of particular importance. On the one hand, its mission is to ensure the free coexistence of humans on the planet with each other and with other species. On the other, it establishes the normative regulation of human interaction. It is fair to note that humanity transmits a certain pattern of thinking, behavior, evaluations, and preferences. In addition, in their content, these samples are Western European. However, what can be countered as an alternative? Assertion of humanity is the soft management of globalization integration processes. However, pointing to a place of origin is not a counterargument in essence. Therefore, there is every reason to believe that such a scenario is acceptable.

In the course of the analysis of the concept of humanity, of all its contradictions and advantages, there is a stable allusion to the Heidegger concept of human being as a concern. According to this system of fundamental ontology, it is expedient to interpret humanity as a human way of assisting in the realization of another being, in the realization of one's future as a project, as a strategy of survival. In this context of interpretation, any particular principles lose their power and influence. For that reason, in the general sense of the concept, humanity is an existentially human way of realization of the world and the world of being, the selfrealization in the horizon of the eternal truth of Being. However, modernity initiates the need to revise the concept of humanity and to review the mechanisms of humanistic development of Humanity. 


\section{Image of Human in $21^{\text {st }}$ century: Challenges, Contradictions and Possibilities}

The article seeks to resolve the problem of preserving humanity in the genesis of civilization, grounding on traditional (modern) conceptions of man as a carrier of specific ideological orientations, as the embodiment of a certain anthropological project of the Modernity era. Logically, the question arises as to how the sociocultural mechanisms for the implementation of this project can be provided in the new social architecture (Kyvliuk \& Svyrydenko, 2017). For us, the research interest is both the very concept of Man for the new socio-cultural way and the mechanisms of its implementation in the current conditions, in particular, the role of education in transmitting humanistic ideals. Modernity calls into question rationality as a tool for resolving moral contradictions, which must be appropriately reflected by philosophy in general and philosophy of education in particular: "In the contemporary space of philosophical options on numerous moral subjects, prime real estate clusters around a doctrine asserting the existence of a surpassingly significant (and usually also unique) moral feature - named by the name of Rationality, with a capital ' $R$ ' - that is purportedly, even palpably, shared by all members of the human" (Thalos, 2002: 86). Indeed, the marginalization of rationality is able to create favorable conditions in society for the actualization of the dark side of human nature.

In this case, we view human not only through the prism of current fundamental transformations, but also as the embodiment of a certain anthropological project within the framework of active processes of space exploration. Can Humanity, in its ready, modern form, "delegate" space program participants? Are they capable of being carriers of the same anthropological project without pre-preparing for a long stay in small social groups? Can education prepare a person for a long, conflict-free space voyage, and can that person act as a driving force for building a civilization project on other planets?

Traditionally, in implementing an anthropological project, society relies on developed social institutions to provide it (economy, education, family, etc.). However, Humanity is faced with a situation that is difficult to deploy into a real social practice, because it requires a fundamental revision of the status roles of all institutions familiar to society. In its sense, such revision can often lead to a complete neutralization of the value of certain mechanisms, bringing to the forefront of the social progress of new "players". One way or another, revision of ideas about the place of social institutions is inevitable. At the same time, the intellectuals of the modern world have been emphasizing for several years that the advancement of the new millennium must take place with the involvement of the intellectuals of society (world philosophical congresses can serve as an example in this regard). A prominent thinker of the present, Ralph Dahrendorf, twenty years ago, emphasized that technological progress deprived intellectuals of social status in their own enthusiasm for technocratic ideals, and the new social order can easily go the way, which is destructive to civilization: "Intellectuals are responsible to society. Societies, where they are dumb, are deprived of the future. Intellectuals may or may not wish to be on one's side in the struggle of blind faith-based positions, though if all of them are on one side, then something is wrong. It is the duty of intellectuals to express clearly existing views and thus to appeal to those who bear the hardships and tribulations of real life. At the end of the twentieth century, the social contract of the Age of Enlightenment between ideas and practical actions may have partially lost its charm, but in no way lost its significance as an engine of freedom "(Dahrendorf, 1997). 
Indeed, intellectuals, universities, and the education system have an important social mission to ensure the impartial search for truth and the preservation of human in society, but the rejection of these ideals is another challenge: society will be deprived of reference points in its own dynamic progress. Accordingly, will education have its own traditional status in the translation of value horizons if their formulation remains beyond intellectual discussions in the educational environment?

New Enlightenment now emerges as a philosophical concept that seeks to preserve the achievements of the Age of Enlightenment, while modernizing it as an imperative for human development in the third millennium. In our opinion, it does not in the least take into account the prospects of comprehending the cosmos, extrapolation of our civilization to other planets, which needs a specific outlook. One of the New Enlightenment apologists is Steven Pinker, and his concept can be briefly described as follows: "Can humanity save itself? Steven Pinker wrote Enlightenment Now to prove that the industrial and scientific revolutions have enormously speeded up the rate of social change since the middle of the nineteenth century. We are in fact experiencing a new enlightenment now. He writes about Enlightenment thinkers of the eighteenth century who valued reason, science, humanism, prosperity and peace above all else. In emphasizing that the innate human capacity of sympathy for others can allow us to embrace all humanity, not just one's tribe, village, ethnicity, state, or small part of the planet, they recognized the possibility of the universal improvement of life" (Sharpe, 2018: 2010).

Contemplating with the space scientists who distance themselves from the problems associated with space exploration, Olen Shevniuk and Olena Matviienko claim: "What is the moral value of the decisions that technology makes? Who should bear moral responsibility for failures in technology and for the consequences of those errors that led to the failures in information and communication technology?... Solving the problem of moral values on board the manned spacecraft is a sine qua non for artistic freedom during a space flight, the quality of the tasks associated with the colonization of the outer space and the development of material, energy and information resources of the universe" (Shevniuk \& Matviienko, 2019: 128). Thus, limiting the discourse of Humanity's perspectives to planetary boundaries is a threat to the implementation of a renewed anthropological project. In our opinion, New Enlightenment should take into account not only the current planetary problems of human development, but also the prospects of extending an updated anthropological project across the Universe.

The logical question arises whether education can teach modern man to think within the cosmic scale, to understand the processes of space exploration in the humanistic tradition, or, for example, within the dehumanist colonial, resource-oriented ideology. Will humanity be able to remain "human" without turning space activities into a struggle for resources when the utilitarian programs of individual states marginalize the interests of Humanity as a whole?

\section{Conclusions}

Therefore, the authors managed to consider the problem of "Learning to be Human", which was themed at the latest World Congress of Philosophy (2018), supplementing its content with the contradictions resulting from space exploration by Humanity. It was possible to emphasize that the ideals of Modernity are threatened by the contradictions of civilizational progress, and Humanity is less and less hopeful about the possibilities of education in ensuring harmonious civilizational progress.

Leading intellectuals of the world emphasize that Humanity should re-vitalize the ideals of Enlightenment in the current socio-cultural context (technological advances, intensive 
intercultural communication, etc.) by offering the concept of New Enlightenment. The article attempted to substantiate the ability of New Enlightenment to guide the modernization of society as a whole, as well as to provide an ethical platform for new education that would harmonize social relations in the face of globalization and technological challenges, as well as in the light of the contradictions associated with human development. Classical Enlightenment, formulating an anthropological project several centuries ago, proceeded from the socio-cultural conditions of the time; hence, as an example, it cannot offer universal "recipes" for solving contemporary contradictions of the globalization, technological and space-related agenda in its traditional form. At the same time, New Enlightenment can suggest a personalized ethical platform for Humanity that can be appropriately transmitted by value-updated education tools.

\section{[D] References}

Dahrendorf, Ralph. (1997) The Public Responsibility of Intellectuals: Against the New Fear of the Enlightenment. http://www.polisportal.ru/files/File/puvlication/Starie_publikacii_ Polisa/D/1997-6-2-Darendorf_grazhdanskaya_otvetstvennost_intellektualov.pdf (in Russian)

Donnelly, Jack. (2015) Normative Versus Taxonomic Humanity: Varieties of Human Dignity in the Western Tradition. Journal of Human Rights, Volume 14, Issue 1, 1-22. https:// doi.org/10.1080/14754835.2014.993062

Frick, Johann. (2017) On the survival of humanity. Canadian Journal of Philosophy, Volume 47, Issue 2-3: Ethics and Future Generations, 344-367. https://doi.org/10.1080/0045 5091.2017.1301764

Gill, Michael B. (2016) Love of humanity in Shaftesbury's Moralists. British Journal for the History of Philosophy, Volume 24, Issue 6, 1117-1135. https://doi.org/10.1080/09608 788.2016 .1198303

Hartley, John. (2010) Homo Nuntius — Messaging Humanity. Popular Communication._The International Journal of Media and Culture, Volume 8, Issue 4, 293-311. https://doi. org/10.1080/15405702.2010.512830

Heyd, David. (2003) Human Nature: An Oxymoron? Journal of Medicine and Philosophy, Volume 28, Issue 2, 151-169. https://doi.org/10.1076/jmep.28.2.151.14205

Kleszczyński, Kamil. (2019) Games and the Future of Man. Gamification as a Transhumanist Program. Future Human Image, Volume 12: 53-63. https://doi.org/10.29202/fhi/12/4

Kyvliuk, Olga, and Denys Svyrydenko. (2017) Academic mobility as "brain drain" phenomenon of modern higher education. Studia Warmińskie, Vol. 54, 361-371.

Lattimore, John, and Mickey Lauria. (2018) Collective efficacy in disadvantaged neighborhoods: The influence of Habitat for Humanity. Journal of Urban Affairs, Volume 40, Issue 6, 782-804. https://doi.org/10.1080/07352166.2017.1392829

Learning to be Human. 24 $4^{\text {th }}$ World Congress of Philosophy. (2018) http://wcp2018.pku.edu. cn/docs/20170921134038365819.pdf

Lee, Joseph. (2013). The Human Dark Side: Evolutionary Psychology and Original Sin. Journal of Religion and Health, Volume 53, Issue 2, 614-629. https://doi.org/10.1007/ s10943-013-9805-z

Malachuk, Daniel S. (2010) Human Rights and a Post-Secular Religion of Humanity. Journal of Human Rights, Volume 9, Issue 2: Comparative Human Rights: Literature, Art, Politics, 127-142. https://doi.org/10.1080/14754831003761647

Mester, Béla. (2012) Human Nature and the Nature Itself: Natural and Social Aspects of the 
Human Nature. Limes: Borderland Studies, Volume 5, Issue 2, 71-81. https://doi.org/ $10.3846 / 20297475.2012 .668721$

Philosophy as inquiry and way of life. $23^{\text {rd }}$ World Congress of Philosophy. (2013) http://www. athenscvb.gr/en/content/xxiii-world-congress-philosophy

Pinker, Steven. (2018) Enlightenment Now: The Case for Reason, Science, Humanism, and Progress. New York: Viking.

Robinson, Brian, Vasko, Stephanie E., Gonnerman, Chad, Christen, Markus, and Michael O'Rourke. (2016) Human values and the value of humanities in interdisciplinary research. Cogent Arts \& Humanities, Volume 3, Issue 1. https://doi.org/10.1080/233 11983.2015.1123080

Sharpe, Michael. (2018) Steven Pinker and the New Enlightenment. Challenge, Volume 61, Issue 2, 210-211. https://doi.org/10.1080/05775132.2018.1457466

Shevniuk, Olena, and Olena Matviienko. (2019) Moral Values and Skills: The Challenges of Space Exploration Practices. Philosophy and Cosmology, Vol. 23, 121-129. https:// doi.org/10.29202/phil-cosm/23/11

Schüller, Andreas. (2010) Fundamental standards of humanity - still a useful attempt or an expired concept? The International Journal of Human Rights, Volume 14, Issue 5. https://doi.org/10.1080/13642980903156875

Svyrydenko, Denys, and Olena Yatsenko. (2019) Science education as a way of transforming an anthropological project into human capital. Dilemas contemporaneos educacion politica y valores. Vol. VII, Special Issue: October, 2019. https:// dilemascontemporaneoseducacionpoliticayvalores.com/_files/200006061dec72dec74/19.10.19\%20La\%20educaci\%C3\%B3n\%20cient $\%$ C3\%ADfica $\% 20$ como $\% 20$ una $\% 20$ forma $\% 20 \mathrm{de} \% 20$ transformar $\% 20 \ldots . .$. .pdf

Thalos, Mariam. (2002) From Human Nature to Moral Philosophy. Canadian Journal of Philosophy, 32:sup1, 84-127. http://dx.doi.org/10.1080/00455091.2002.10717584

Woolfson, David. (2000) Humanity's evolutionary future. World Futures. The Journal of New Paradigm Research. Volume 55, Issue 3, 183-200. https://doi.org/10.1080/0260 4027.2000.9972780 